\title{
Managing logistical supply chain drivers: A predictor of small township retailers' odds of survival
}

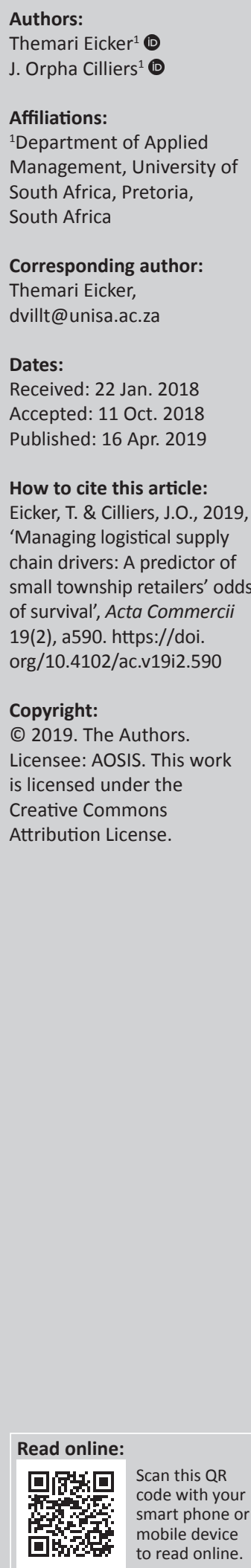

Orientation: Formal independent small Sowetan retail businesses operate under challenging economic conditions that impede their ability to survive. However, the management of the logistical supply chain drivers can increase these small retailers' odds of survival.

Research purpose: To investigate whether the management of the logistical supply chain drivers can serve as a predictor of formal independent small Sowetan retail businesses' odds of survival.

Motivation for the study: Assisting formal independent small Sowetan retail businesses to integrate with local and formal supply chains, as well as increasing their odds of survival amidst the difficult economic conditions under which they operate.

Research design, approach and method: A quantitative survey was conducted among 650 formal independent small Sowetan businesses, of which the responses of 556 retailers were analysed. Two binary logistic regression models were developed to determine whether the management of the logistical supply chain drivers could predict the small retailers' odds of survival.

Main findings: The results of two binary logistic regression models showed that the management of the three logistical supply chain drivers influences the odds of formal independent small Sowetan retail businesses surviving for 5 years or longer, as well as their odds of growing their annual income.

Practical/managerial implications: Assisting policymakers when designing developmental initiatives for townships.

Contribution/value-add: This study strives to assist formal independent small Sowetan retail businesses operating within a developing country to manage their logistical supply chain drivers to increase their odds of survival and contribute to the economic development of their country.

Keywords: business age; logistical supply chain drivers; facilities; income; inventory; transportation; small retailers; Soweto; survival; townships.

\section{Introduction}

Small businesses have been studied extensively worldwide as a cardinal driving force behind income growth and prosperity for individuals and communities (Abor \& Quartey 2010:218; Aykan, Aksoylu \& Sönmez 2013:939; Katz \& Green 2012:14; Mbonyane \& Ladzani 2011:550). The economic importance of small businesses particularly in developing countries for job creation, poverty alleviation and increased employment growth rates has been investigated by numerous authors and forms the focal point of various policymakers (Deijl, De Kok \& Essen 2013; Jamali, LundThomsen \& Jeppesen 2017). In South Africa as a developing country, small businesses are thus also prioritised as a way to create employment; to ensure a more equal distribution of income to citizens; to promote the general economic welfare of citizens; and to improve local markets (Nkosi, Bounds \& Goldman 2013:1). In South Africa's National Development Plan of 2030, the continued commitment of the South African government to prioritise the development of small businesses is reflected in their ambitious goal for the small business sector to create $90 \%$ of the employment opportunities within South Africa by 2030 (South Africa, National Planning Commission 2012). Policymakers of South Africa's National Development Plan of 2030 focused specifically on the development of small businesses in townships, which includes the development of the owners and managers of these businesses (South Africa, National Planning Commission 2012).

The South Western Township (hereafter referred to as 'Soweto') is South Africa's largest township, with 1271628 inhabitants, and has been identified as a key retail growth point of the country based 
on annual spending power of R5 billion. This annual spending power, together with lucrative business opportunities, resulted in Soweto being the focus of numerous policymakers for governmental developmental initiatives aimed at small township businesses (Prinsloo 2014:6; South Africa, National Planning Commission 2012; Statistics South Africa [Stats SA] 2011). Unfortunately, the percentage of South African small businesses that close down within the first 5 years is a staggering 80\% (Strydom 2015:467; Van Eeden, Viviers \& Venter 2003:12). Because small businesses can enhance a country's economic growth, research conducted in this regard will not only benefit businesses but also promote economic growth (Nkosi et al. 2013:1).

\section{Background}

Over the past two decades, several studies have been conducted on the previously disadvantaged townships of South Africa and particularly on their development. These studies focused on key issues such as challenges faced by township entrepreneurs and the support of the government (Olawale \& Garwe 2010); the status of township businesses and entrepreneurs within Gauteng (Strydom 2015); the survival of formal small businesses in Soweto (BadenhorstWeiss \& Cilliers 2014); the unique market offering by formal independent retail and wholesale small businesses in Soweto (Badenhorst-Weiss, Cilliers \& Eicker 2014); and the skills required for the management of black-owned small enterprises in Soweto (Nkosi et al. 2013). The continuation of such studies can be ascribed to the drastic changes in the township business environment - from unplanned business infrastructures to state-of-the-art shopping malls-influencing the way in which these businesses are operated and managed (Nkosi et al. 2013:4).

During the apartheid years, townships such as Soweto were characterised by rows of uniform houses and a lack of infrastructure, such as roads, sanitation, water and electricity (World Bank 2014:4). Townships only had basic retail infrastructure because of restricted economic activities within the townships pre-1994 (Strydom 2011:151). This era was characterised by clustered, small formal neighbourhood centres, with the majority of businesses classified as general retailers, which included spaza shops (retailers operating from a room in a house), shebeens (retailers selling beer and other liquor) and hawkers (retailers selling mainly perishable products) (Strydom 2011:152).

After 1994, the new South African government prioritised the development of black-owned businesses, which included the development of small businesses in townships (Rogerson \& Rogerson 1997:33). Policymakers developed numerous initiatives, such as the Soweto Retail Strategy of 2005; the Five-Year Soweto Economic Development Plan 2008-2013 and the Township Economy Revitalisation Action Plan of 2014, to stimulate Soweto's economic activity after the city was incorporated into the Greater Johannesburg Metropolitan Municipality in 2001.
Although the Gauteng Department of Economic Development acknowledged the numerous initiatives aimed at developing townships (which included the erection of large shopping malls), they were concerned that townships were still characterised by low levels of entrepreneurial activities, a low survival rate of small businesses and a lack of business skills by the owners and managers of these businesses (Gauteng Department of Economic Development 2014:4-5). Research by Strydom (2013:2870) on the patronage of Sowetan retailers established that the high-income group still mainly bought high-value items outside the township and that individuals shopping within the township (so-called inshoppers) formed part of the middle- to lower-income groups. It therefore seems that the retailers located within Soweto have mainly been serving the price-sensitive inshoppers (Strydom 2011:2870).

In 2014, the World Bank conducted an extensive study in Diepsloot in order to understand, among others, the structure of a township's economy. Diepsloot, which has been described as a developmental township, is situated in the northern part of Johannesburg (Diepsloot 2017). The Gauteng Department of Economic Development (2014:9) regards this study as the most intensive study on South African townships to date. The World Bank study found that the difficult economic conditions under which township entrepreneurs operate could be attributed primarily to the high unemployment rate and the lack of integration between local (supply chains within townships) and formal supply chains (supply chains outside the boundaries of the township) (World Bank 2014:10). The need for integrating formal and informal supply chains has been the focus of several other studies conducted on South Africa small businesses, for example Peyton, Moseley and Battersby's (2015) research on addressing urban food security in Cape Town, Das Nair and Dube's (2015) research on the implications of regional supermarket chains on local suppliers capabilities in Southern African countries and Louw and Jordaan's (2016) research on Gauteng smallholder fresh produce farmers' supply chain risks. The report stressed that supply chains had to be strengthened, mainly through supply chain integration, for township economies to improve (World Bank 2014:22-23), which implies strong relationships and skilled processes spanning within and across the township boundaries as emphasised in the subsequent section.

\section{Problem statement}

Globalisation and the rapid development of technologies have led to a shift from businesses competing against each other to supply chains competing against each other (Alfalla-Luque, Mendina-Lopez \& Dey 2013:800; Qrunfleh \& Tarafdar 2013:571; Simon et al. 2015:28). Supply chains compete in satisfying customers' needs either in terms of speed (responsiveness) or cost (cost-efficiency) (AlfallaLuque et al. 2013:800; Ambe 2012:126; Chi, Kilduff \& Gargeya 2009:649; Hines 2013:258; Qrunfleh \& Tarafdar 2013:571; Simon et al. 2015:28). Chopra and Meindl (2016:56) explain 
that obtaining the correct level of responsiveness and costefficiency depends on the unique interaction of the different elements within the supply chain, known as the supply chain drivers. All members within a supply chain should manage their supply chain drivers as a coordinated and cohesive singular competing unit in order to satisfy the needs of end-customers (Alfalla-Luque et al. 2013:800; Monczka et al. 2016:13; Wisner, Tan \& Leong 2016:8).

Six supply chain drivers are identified in the literature (Badenhorst-Weiss, Van Biljon \& Ambe 2017:40; Chopra \& Meindl 2016:56), namely sourcing, pricing, information, facilities, inventory and transportation. The focus of this article is on the three logistical supply chain drivers, namely facilities, inventory and transportation, and more specifically their role in predicting small township retailers' survival.

A competitive advantage depends on building relationships and processes beyond the boundaries of their business to assist in the design, production and delivery of goods and services according to customers' needs (Fawcett, Ellram \& Ogden 2007:6; Wisner et al. 2016:8). Logistics is the activity that facilitates these relationships between the different businesses within the supply chain by coordinating the flow of products, services and information (Christopher 2016:2). Consequently, business owners can build relationships among the different role players or businesses in their supply chain by managing the logistics activity (Bowersox et al. 2013:4, 29, 33; Wisner et al. 2016:301).

Considering the difficult economic conditions under which township entrepreneurs operate, specifically the lack of supply chain integration between local and formal supply chains within townships and the importance of the logistics activity in building relationships and processes among the different supply chain members, the aim of this article is to investigate whether the management of the logistical supply chain drivers can serve as a predictor of formal independent small Sowetan retail businesses' odds of survival.

This article is structured to firstly provide a literature review highlighting the different management decisions that owners and managers need to make regarding the logistical supply chain drivers. After the research methodology has been discussed, two binary logistic regression models are developed to determine whether the management of the logistical supply chain drivers is a predictor of the survival of the formal independent small retail business in terms of their age and annual income.

\section{Literature review}

As discussed previously, supply chains compete either more responsively or more cost-efficiently based on customers' needs and the businesses' capabilities. Chopra and Meindl (2016:38) emphasise the positive contribution of the management of the logistical supply chain drivers (in alignment with the overall level of responsiveness and cost-efficiency of the entire supply chain) to the survival of a business. The management of the different logistical drivers is discussed in the following subsections by referring specifically to its influence on the businesses' overall level of responsiveness and cost-efficiency.

\section{Facilities}

In facilities, supply chain services such as storage, customer order fulfilment and product assembling are provided. If these services are managed and designed to promote responsiveness, it can result in improved customer service (Wisner et al. 2016:318). Because facilities can serve as a source of competitive advantage, based on reducing either cost or lead times (Graungaard Pedersen, Zachariassen \& Stentoft Arlbjørn 2012:354), managers must ensure that the appropriate facility network is designed, in terms of function, location and capacity (Bowersox et al. 2013:37).

Traditionally, the functionality of facilities has only been regarded as a place where products are stored, but more recently its functionality also includes the mixing and modifying of products according to a customer's orders (Wisner et al. 2016:319). Facilities can be classified according to their function as a production facility, where inventory is assembled, manufactured, modified or fabricated; as a storage facility where inventory is stored; as a distribution centre where inventory is cross-docked; as the premises from which a retailer operates; and as a service facility where a service is rendered to a customer by using an inventory component (Bowersox et al. 2013:37; Lawrence, Sivakumar \& Arivarignan 2013:4771). According to Kotler et al. (2013:435), managers within the retail sector should bear in mind their target market when designing or selecting the retail facilities. Factors such as product variety and level of shopping convenience will influence the size and layout of the retail facility. For example, a responsive facility will be more streamlined to assist customers speedily. According to the World Bank (2014:46), most township entrepreneurs have the necessary start-up capital to purchase (or rent) a facility from which to operate their businesses but find it difficult to acquire facilities (regardless of the function) because of the general lack of retail space within townships.

Responsive facilities will usually be decentralised, in order to be closer to customers for faster product delivery. However, such high responsiveness usually comes at a high cost. On the other hand, cost-efficient facilities will usually be centralised, to dispatch products to customers from one central facility. Although central facilities would increase the cost-efficiency of facilities, the responsiveness of the business might decrease (Baily et al. 2008:58-59). According to the World Bank (2014:153), the owners and managers of businesses in Diepsloot are aware that being located close to their customers is an advantage, because their customers mainly reside in the neighbourhood and generally walk to the retailer from their homes or from taxi ranks. The World Bank (2014:163) further reports that these owners and managers indicated that instead of expanding their current 
shops (facilities), they would rather open more shops at different locations (decentralising) in order to be closer to more customers.

The scope of excess capacity in a facility as well as the utilisation of such excess capacity has a direct impact on the level of responsiveness and cost-efficiency. Although utilising excess capacity (if available) can increase the level of responsiveness by having the ability to respond swiftly to changes in customer demand, cost-efficiency will decrease, as idle capacity does not generate revenue and also increases facility costs (Hugos 2006:10-11; Kamath \& Roy 2007:336). The World Bank reports that business owners in townships experience a lack of storage space, which influences the amount of inventory purchased (World Bank 2014:207).

It is evident from the literature that management decisionmaking should consider the impact of facility location and flexibility on the level of responsiveness and cost-efficiency of a facility - and ultimately on the level of responsiveness and cost-efficiency of businesses in serving customers competitively (Chopra \& Meindl 2016:58-59).

\section{Inventory}

Inventory is kept in supply chains to address the imbalance between the supply and demand of products (Chopra \& Meindl 2016:61). The challenge for managers lies in finding the right balance between the amount of inventory that businesses should carry to satisfy unpredictable customer demand and the cost of carrying additional inventory (Ehrenthal, Honhon \& Van Woensel 2014:527; Pienaar \& Vogt 2012:218). Within many businesses, inventory is one of the most expensive assets and should be managed effectively (Monczka et al. 2016:621-622; Wisner et al. 2016:209). Effective inventory management implies that the right amount of inventory is purchased to support a business's day-to-day activities, whereas ineffective inventory management can lead to excess inventory and a waste of resources (Wisner et al. 2016:209). To ensure effective inventory management, managers need to consider the number of cycle, safety and seasonal inventory items held (Chopra \& Meindl 2016:61).

According to the World Bank (2014:173, 175), small businesses in townships in Gauteng usually purchase inventory from Marabastad (a market situated in Pretoria), large wholesalers (e.g. Makro) and business associates (e.g. Muslim retailers purchasing from others in the Muslim community). These retailers usually search for the lowest prices among the different suppliers, as lower purchasing will lower prices, allowing them to charge less for products than competitors (World Bank 2014:173). On average, these small retailers purchase inventory every 2 weeks (World Bank 2014:153, 155, 172).

Businesses will carry additional inventory in anticipation of future customer demand or in preparation for an event, such as a sale or the holiday season. High levels of stored inventory will increase a businesses' responsiveness at the expense of cost-efficiency (Baily et al. 2008:164). Many businesses prefer high inventory levels and would rather pay the additional storage cost, in order to gain the advantage of economies of scale. Sourcing high quantities of products at a lower price per unit will increase a businessess' responsiveness level (Fawcett et al. 2007:150). Some township businesses are known to coordinate with other businesses when purchasing inventory in bulk, in order to gain the advantage of economies of scale (World Bank 2014:173) - something they would not be able to do on their own. According to the World Bank (2014:207), almost $20 \%$ of business owners in townships reported that they cannot purchase excess (safety) inventory as they do not have space to store it.

The preceding literature shows that the level of responsiveness and cost-efficiency at which inventory is managed is mainly influenced by the number of inventory items that managers decide to hold based on customer demand, storage availability and possible investment in inventory.

\section{Transportation}

Transportation can be described as the movement of inventory from one point to another, because products are seldom produced, sold and consumed at the same location (Goldsby, Iyengar \& Rao 2014:4-5; Nwaogbe et al. 2013:1). Transportation, as one of the largest logistical expenses for any business, can influence the success of both the individual business and the supply chain in which the business functions and should therefore be managed effectively and costefficiently (Bowersox et al. 2013:187; Chopra \& Meindl 2016:431). Holter et al. (2008:22) not only emphasise the importance of transportation decisions because of the substantial investment in transportation, but also since transportation is a process that is repeated numerous times throughout the supply chain. Therefore, transportation is generally the most costly logistical activity for many small businesses. Effective transportation management refers to the extent that transportation contributes to meeting customer needs; whereas cost-efficient transportation management measures how transportation can contribute economically in meeting customer needs (Bowersox et al. 2013:187).

Managers should design a transportation network that will assist a supply chain in achieving the desired level of responsiveness at the lowest possible cost (Chopra \& Meindl 2016:64). The desired level of responsiveness can be achieved through a transportation mode that is fast and flexible, whereas the desired level of cost-efficiency can be achieved through transporting products in larger batches and less often. The higher the desired level of responsiveness, the less cost-efficient transportation will be, as faster and more flexible transportation is associated with higher costs. On the other hand, a supply chain can maintain a higher level of cost-efficiency by deciding on slower (and lower priced) transportation options and transporting in larger batches at the cost of being responsive (Chopra \& Meindl 2016:63; Nel 2010:172). 
Small retailers in Diepsloot find it easy to transport their inventory and have experienced that keeping transportation costs low provides a competitive advantage. If the owner or manager of a small business in Diepsloot collects inventory from a supplier themselves, the average transportation costs are between R300 and R350 per trip (World Bank 2014:153, 172). Township retailers who purchase inventory in large quantities from wholesalers do not have any transportation costs, as the wholesalers usually provide free delivery to these customers. However, many small businesses in Gauteng townships have no other option than to purchase inventory from markets (such as Marabastad in Pretoria) and other small businesses that do not offer delivery services (World Bank 2014:151-153, 172-173, 206).

Township retailers who purchase smaller quantities of inventory have to travel to wholesalers that are located within a reasonable distance from their stores, by using public transport (taxis in the form of minibuses) or by hiring a small truck (referred to as a bakkie) (World Bank 2014:151-153, 172-173). This is in line with Goldsby et al. (2014:24), who state that small businesses primarily use road transportation by selecting small trucks and motor vehicles to transport inventory back to their stores. Although road transportation could increase a retailer's level of responsiveness in terms of flexibility, it simultaneously decreases the level of cost-efficiency because of higher operating costs (Hugo \& Badenhorst-Weiss 2011:179-180).

From the preceding discussion it can be concluded that small business owners need to consider the mode of transportation as well as the number of inventory items being transported when making transportation management decisions, as the correct balance between responsiveness and cost-efficiency of both the business and the entire supply chain is impacted.

\section{Predictors for the survival of small retailers}

In South Africa, the age of a small business is seen as a measure of survival. In 2011, the present Small Business Development Minister of South Africa, Lindiwe Zulu, stated that only $50 \%$ of small businesses survive past the age of 5 years (SA News 2011). Unfortunately this statistic has decreased from 50\% in 2011 to between $30 \%$ and 20\% in 2016, as was found in a study by the University of the Western Cape (2016) on the survival of South African entrepreneurs in formerly disadvantaged communities. The findings of the University of the Western Cape are in line with those of Old Mutual (2016:1), who reported that in South Africa, the long-term survival rate (reaching the age of 5 years or older) for small and medium enterprises (SMEs) is currently at 37\%. Consequently, any South African small business operating for 5 years or longer can be deemed as surviving. The second predictor of small business survival is annual income growth. The business environment specialists Small Business Project (SBP) compile an annual report on South African SMEs with the aim of establishing an evidence-based understanding of South African SMEs. The SBP (2015:1) reported that in the
2014-2015 financial year, 56\% of the 500 SMEs that were interviewed indicated that their annual income had increased, $20 \%$ indicated that their annual income had stayed the same and $24 \%$ indicated that they had had a decline in their annual income. Because annual growth in income indicates that retailers have expanded their businesses and exploited business opportunities in order to grow and survive during the past year (Ligthelm 2010:137), changes in business income growth are deemed a suitable variable to predict the survival of small businesses. In this article, business age and annual growth in income were selected as predictors of small retailers' survival.

\section{Research methodology}

A survey was conducted in 2014 among a sample of 650 formal independent small businesses operating within the boundaries of Soweto. Formal small businesses are defined as businesses that operate within purpose-built shops, form part of the registered business infrastructure of South Africa, and pay taxes and other levies to different levels of government (Du Plessis, Strydom \& Jooste 2012:56; Ligthelm 2013:59; Strydom 2015:464). The initial list of respondents was developed during a preceding study in 2012 during which trained fieldworkers were strictly instructed to interview only those SMEs complying with all of the following three requirements: forming part of a network of tax registration, registered at the metro and housed in a permanent structure (i.e. a dedicated shop). These requirements were established before interviewing the respondents by means of visual observation and a qualifying question. Despite recent research results making a compelling case to establish enabling policies for the informal sector (Darbi, Hall \& Knott 2018; Fourie \& Kerr 2017; Rogan \& Skinner 2017), many studies conducted within townships preceding this research were primarily focused on formal businesses (Badenhorst-Weiss et al. 2014; Nkosi et al. 2013; Olawale \& Garwe 2010; Strydom 2013, 2015). According to Ligthelm (2013:73), informal small businesses operating within townships are not regarded as the foundation of successful and productive township small businesses. For these reasons, the focus of this study is only on formal small businesses operating within Soweto. The sample of 650 formal independent small businesses included businesses situated in shopping malls, large shopping areas (outside shopping malls), smaller shopping areas, stand-alone businesses and industrial areas with 2-5, 6-10 and 10-plus surrounding businesses but excluded chain stores, franchises, street and in-home businesses. Table 1 provides a summary of the quantitative research methodology used to conduct the 2014 Soweto study.

Of the 650 formal independent small businesses, 556 were classified according to the Standard Industrial Classification (SIC) as operating within the retail sector. The 556 respondents could further be divided, based on the SIC, into six different industries, namely grocery stores (209), hardware stores (42), general stores (88), retail services ${ }^{1}(142)$, eating and drinking 1.'Retail services' refers to, for example, hairdressers and undertakers. 
TABLE 1: Research methodology used to conduct the 2014 Soweto study.

\begin{tabular}{|c|c|}
\hline Research aspect & Description of quantitative empirical research aspect in this study \\
\hline Research area & Defined business areas within Soweto. \\
\hline Survey population & $\begin{array}{l}\text { Formal independent small businesses located within business areas or stands across Soweto. These include businesses situated in shopping malls, large } \\
\text { shopping areas (outside shopping malls), smaller shopping areas, stand-alone businesses and industrial areas with } 2-5,6-10 \text { and } 10 \text {-plus surrounding } \\
\text { businesses. }\end{array}$ \\
\hline Sampling frame & $\begin{array}{l}\text { A list of } 650 \text { formal independent small businesses operating within the boundaries of Soweto was compiled by the BMR in } 2012 \text {. The list of small businesses } \\
\text { compiled in } 2012 \text { was used as the sample frame for this study. If a business closed down during the } 2 \text {-year period, fieldworkers were instructed to select any } \\
\text { business in the same residential area that complied with all the requirements (i.e. any formal independent small businesses located within business areas or } \\
\text { stands across Soweto). These include businesses situated in shopping malls, large shopping areas (outside shopping malls), smaller shopping areas, } \\
\text { stand-alone businesses and industrial areas with } 2-5,6-10 \text { and } 10 \text {-plus surrounding businesses. }\end{array}$ \\
\hline Sampling method & $\begin{array}{l}\text { Probability sampling using a stratified sampling method as each formal independent small business in the population had the same probability of being } \\
\text { selected. }\end{array}$ \\
\hline Sample units & The business owners or managers of the formal independent small businesses. \\
\hline Research instrument & $\begin{array}{l}\text { Structured interviewer-completed questionnaires consisting of close-ended questions, using nominal and ordinal measurement scales. The close-ended } \\
\text { questions were formulated and based on relevant literature. }\end{array}$ \\
\hline $\begin{array}{l}\text { Collecting, coding } \\
\text { and capturing of data }\end{array}$ & $\begin{array}{l}\text { The fieldwork was coordinated by the BMR and the data was gathered within } 7 \text { weeks (July through August) by five fieldworkers. Data was captured on } \\
\text { Excel and SPSS (version 23). }\end{array}$ \\
\hline Primary data collection & $\begin{array}{l}\text { Quantitative primary data collected through interviewer-administrated surveys. Personal face-to-face interviews with owners or managers of the small } \\
\text { businesses. }\end{array}$ \\
\hline $\begin{array}{l}\text { Ethical } \\
\text { considerations }\end{array}$ & $\begin{array}{l}\text { The fieldwork was conducted within the directives of the ethical policy of the university, which encourages that research respect the autonomy, rights and } \\
\text { dignity of research participants, make a positive contribution towards the welfare of people, not cause harm to the research participants in particular or } \\
\text { to people in general and that the benefits and risks of research should be fairly distributed among people. }\end{array}$ \\
\hline
\end{tabular}

BMR, Bureau of Market Research.

places (39) and retail auto (36). The strong representation of retailers in the respondent group is a reflection of the vibrancy of the retail industry in Gauteng, especially in townships (Gauteng Quarterly Bulletin 2012:26), as one way of addressing the consequences of the history of black capitalism, where the apartheid system hindered access to business opportunities for black people (Mtshali, Mtapuri \& Shamase 2017:2). The empirical findings from the data relating to the three logistical supply chain drivers presented in this article are based on the 556 formal independent small retailers (hereafter referred to as 'small retailers'). The next section starts by describing the small retailers in terms of the two measures of survival for small businesses as identified through literature, namely business age and growth in annual income, whereafter the results of the two binary logistic regression models are discussed.

\section{Ethical considerations}

The fieldwork was conducted within the directives of the ethical policy of the university which promotes that research should respect the autonomy, rights and dignity of research participants, make a positive contribution towards the welfare of people, not cause harm to the research participants in particular or to people in general, and that the benefits and risks of research should be fairly distributed among people. Ethical approval was obtained from the Bureau of Market Research (BMR) Research Ethics Committee (REC) and 2014 Small Business Survey (CR060).

\section{Results of the study \\ Description of the small retailers in terms of the identified survival predictors}

Questions relating to age and annual growth in income (reported in yearly income change patterns) were included in the questionnaire in order to establish a profile of the small retailers in terms of their survival. It was found that $59.4 \%$ of the 556 small retailers had existed for 5 years or longer.
In terms of annual income patterns, 25\% had expanded, $48 \%$ had contracted and $26 \%$ had remained the same. Although the majority of small retailers had been operating for 5 years or longer, their annual growth (expansion) in income was well below the $56 \%$ reported by the SBP $(2015: 1)$. Given the challenging economic conditions under which township entrepreneurs operate, these small Sowetan businesses managed to exist for 5 years or longer; however, they were not reaching their full potential, as seen in the low percentage of retailers reporting an increase in annual income.

\section{Inferential analyses}

After describing the small retailers in terms of their age and annual income growth, two binary logistic regression models were developed using the 556 respondents' responses in terms of the three logistical supply chain drivers to determine whether the management of the three logistical supply chain drivers influences the small retailers' odds of survival in terms of age and income growth. Binary logistic regression is a statistical method used to determine whether one or more independent variables can be used to predict a dichotomous dependent variable (Berger 2017:2). It should be noted that the binary regression models were developed to identify potential statistical significant predictors of the odds of small retailers' survival and not to build a predictive model.

\section{Independent variables}

The set of independent variables that was used in the binary logistic regression models was derived from the questions in the questionnaire on the management of the three logistical supply chain drivers. Table 2 provides a list of the questions (as stated in the questionnaire) that were used as independent variables in the binary logistic regression models.

Hosmer and Lemeshow (2000:92) state that the more independent variables included in a binary logistic regression model, the greater the estimated standard errors become. 
TABLE 2: Actual questions pertaining to the management of the logistical supply chain drivers.

\begin{tabular}{|c|c|c|}
\hline $\begin{array}{l}\text { Logistical supply } \\
\text { chain driver }\end{array}$ & $\begin{array}{l}\text { Question } \\
\text { number }\end{array}$ & Question \\
\hline \multirow[t]{6}{*}{ Facilities } & E2 & How often, on average, do you purchase inventory? \\
\hline & E3j & $\begin{array}{l}\text { Frequency of having capacity to store excess } \\
\text { inventory in the retailer's store. }\end{array}$ \\
\hline & E3k & Frequency of accessing inventory quickly and easily. \\
\hline & E11j & $\begin{array}{l}\text { Level of importance to the retailer to be located } \\
\text { near customers. }\end{array}$ \\
\hline & E11k & $\begin{array}{l}\text { Level of importance to the retailer to be located } \\
\text { near public transport. }\end{array}$ \\
\hline & E11m & $\begin{array}{l}\text { Level of importance to the retailer to provide } \\
\text { customers with a fast checkout. }\end{array}$ \\
\hline \multirow[t]{12}{*}{ Inventory } & E3a & $\begin{array}{l}\text { Frequency of purchasing less inventory than what } \\
\text { the retailer sells within a month. }\end{array}$ \\
\hline & E3b & $\begin{array}{l}\text { Frequency of purchasing the exact amount of } \\
\text { inventory that the retailer sells within a month. }\end{array}$ \\
\hline & E3c & $\begin{array}{l}\text { Frequency of purchasing more inventory than what } \\
\text { the retailer sells within a month. }\end{array}$ \\
\hline & E3d & $\begin{array}{l}\text { Frequency of finding it too expensive to purchase } \\
\text { more inventory than what the retailer sells within } \\
\text { a month. }\end{array}$ \\
\hline & E3e & $\begin{array}{l}\text { Frequency of easily obtaining more inventory from } \\
\text { suppliers when the retailer runs out of inventory. }\end{array}$ \\
\hline & E3f & $\begin{array}{l}\text { Frequency of purchasing more inventory when on } \\
\text { sale at the retailer's suppliers. }\end{array}$ \\
\hline & E3g & $\begin{array}{l}\text { Frequency of purchasing more inventory when the } \\
\text { retailer has a sale. }\end{array}$ \\
\hline & E3h & $\begin{array}{l}\text { Frequency of making provision for the fluctuation } \\
\text { in customers' demands (e.g. over Easter and } \\
\text { Christmas). }\end{array}$ \\
\hline & E6a & $\begin{array}{l}\text { Level of agreement of having a product available } \\
\text { immediately when customers want to buy it. }\end{array}$ \\
\hline & E6c & $\begin{array}{l}\text { Level of agreement that customers will know that } \\
\text { the retailer always has enough inventory. }\end{array}$ \\
\hline & E11a & $\begin{array}{l}\text { Level of importance to the retailer of having quality } \\
\text { products. }\end{array}$ \\
\hline & E11c & $\begin{array}{l}\text { Level of importance to the retailer of having enough } \\
\text { product variety. }\end{array}$ \\
\hline \multirow[t]{8}{*}{ Transportation } & $\mathrm{D} 2 \mathrm{a}$ & $\begin{array}{l}\text { Frequency of suppliers delivering inventory directly } \\
\text { to the retailer's store. }\end{array}$ \\
\hline & $\mathrm{D} 2 \mathrm{~b}$ & $\begin{array}{l}\text { Frequency of the retailer paying suppliers to deliver } \\
\text { inventory directly to the retailer's store. }\end{array}$ \\
\hline & $\mathrm{D} 2 \mathrm{c}$ & $\begin{array}{l}\text { Frequency of the retailer paying a supplier more } \\
\text { than a competitor to receive inventory faster. }\end{array}$ \\
\hline & $\mathrm{D} 2 \mathrm{~d}$ & $\begin{array}{l}\text { Frequency of the retailer collecting inventory using } \\
\text { the retailer's own transportation. }\end{array}$ \\
\hline & $\mathrm{D} 2 \mathrm{e}$ & $\begin{array}{l}\text { Frequency of the retailer collecting inventory by } \\
\text { using a transportation opportunity (not using the } \\
\text { retailer's own car). }\end{array}$ \\
\hline & D2f & $\begin{array}{l}\text { Frequency of the retailer taking turns with another } \\
\text { retailer to fetch inventory for both shops. }\end{array}$ \\
\hline & D2g & $\begin{array}{l}\text { Frequency of the retailer being willing to wait } \\
\text { longer to pay less for inventory. }\end{array}$ \\
\hline & D3 & $\begin{array}{l}\text { Would you pay higher delivery costs if your } \\
\text { suppliers can deliver your stock sooner than usual? }\end{array}$ \\
\hline
\end{tabular}

Therefore, the number of independent variables should be minimised in order to produce models that are numerically more stable and more easily generalised (Hosmer \& Lemeshow 2000:92). Principal component analysis (factor analysis) was used to reduce the number of independent variables and to group highly correlated variables together. A principal component analysis could not be conducted on the questions related to the rate of purchasing inventory (E2) and higher delivery cost for earlier inventory delivery (D3), because of these questions being single questions; therefore these items were used as independent variables. Principal component analyses were conducted on the remaining sections of the questionnaire, namely E3, E11, E6 and D2, as these sections contained multiple items. Therefore, these two questions (E2 and D3) were classified as respective items in the set of independent variables of the binary logistics model. Table 3 contains the results of the principle component analyses conducted on Questions E3, E11, E6 and D2.

Considering Table 3, eight factors and two items (E6a having products immediately available and E6c - perception that customers know retailers have enough inventory) were identified after conducting the principal component analyses. Together with rate of purchasing inventory (E2) and paying a higher delivery cost for earlier inventory delivery (D3), 12 independent variables were identified and used in the binary logistic regression models to predict the retailers' odds of survival. The 12 independent variables used in the two binary logistic regression models are summarised in Table 4.

\section{Dependent variables}

In the literature review, business age and annual income growth were identified as appropriate measures of survival of small retailers. Therefore, two binary logistic regression models were conducted, with the dependent variables of business age and annual income growth. The first binary logistic regression model determined the influence of the 12 independent variables on the age (dependent variable) of the small retailers. As the binary logistic regression model can only predict a binomial outcome (one of two possible outcomes), the age of the small retailers was recorded in two categories based on the general rule of thumb on business survival discussed earlier: those in business for less than 5 years and those in business for 5 years or longer. The second binary logistic regression model determined the influence of the 12 independent variables on the annual income growth (dependent variable) of the small retailers. The two categories in which the income growth of the small retailers was recorded were those businesses whose income contracted or stayed the same over the past year and those whose income grew over the past year.

Before discussing the results of the two binary logistic regression models, the following should be noted:

- The Hosmer and Lemeshow test was used to determine whether the model has an acceptable goodness of fit, with a significance level of $p>0.05$ indicating an acceptable fit - that is, the null hypothesis of a fit is not rejected (Esarey \& Pierce 2012).

- Although the null hypothesis for the constant value in the regression is not rejected, it only indicates that the constant value is close to zero. In the case of logistic regression, furthermore, this value is the log of the odds only when all the independent variables are equal to zero. In the binary logistic models tested, zero is outside the range for some of the variables and thus the constant has no meaningful independent interpretation.

\section{Binary logistic regression model: Dependent variable age}

Before the results of the binary logistic regression model are discussed, the following should be noted in terms of the 
TABLE 3: Results of the principle component analyses conducted on Questions E3, E11, E6 and D2.

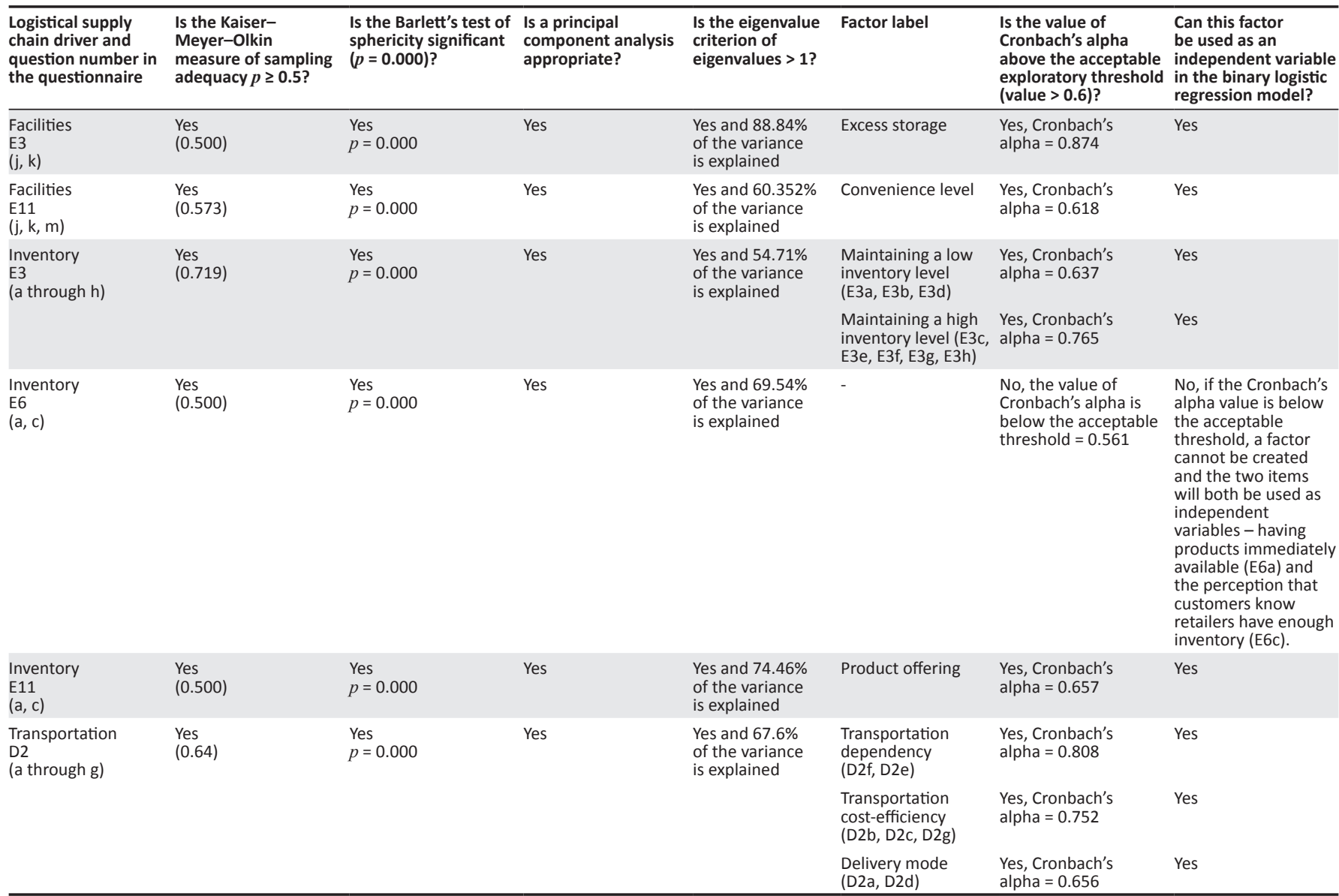

validity and reliability of the logistic regression model predicting the small retailers' survival in terms of age:

- The Hosmer and Lemeshow test indicated goodness of fit of the logistic regression model with a $p$-value of 0.145 . The model is therefore assumed to be adequate.

- The overall correct prediction classification improved from 59\% (Model 0 outcome - the business survives for less than 5 years) to $65.3 \%$ (Model 1 outcome - the business survives for 5 years or longer). Therefore, the results of the binary logistic regression model with the dependent variable for 5 years or longer are discussed.

Table 5 provides the results of the 12 independent variables that were included in the binary logistic regression model. Five independent variables were identified as statistically significant predictors of the model ( $p$-values $\leq 0.05)$. The odds ratios of these five independent variables were considered to determine whether the independent variables had a positive or negative influence on the dependent variable age. An odds ratio larger than 1 indicates that the independent variable increases the small retailers' odds of surviving for 5 years or longer, whereas an odds ratio smaller than 1 indicates that the independent variable decreases the small retailers' odds of surviving for 5 years or longer.

The results indicated that the following independent variables are statistically significant predictors (at the 5\% level of significance) for the age of the business: maintaining a low inventory level; excess storage; transportation dependency; transportation cost-efficiency; and delivery mode. Having allowed for the other variables in the equation, the odds ratios of the 12 independent variables further indicated that:

- Each decrease in frequency of maintaining a low inventory level increases the odds of the business's survival (survive for 5 years or longer) by $79.2 \%\left(\frac{1}{0.558}\right)$.

- Each decrease in the frequency of having excess storage increases the odds of the business's survival (survive for 5 years or longer) by $69.4 \%\left(\frac{1}{0.59}\right)$.

- Each decrease in the frequency of transportation dependency increases the odds of the business's survival (survive for 5 years or longer) by $56.4 \%\left(\frac{1}{0.639}\right)$.

- Each increase in the frequency of transportation costefficiency increases the odds of the business's survival (survive for 5 years or longer) by $108.4 \%(2.084-1 \times 100)$.

- Each increase in the frequency of delivery mode increases the odds of the business's survival (survive for 5 years or longer) by $80.2 \%(1.802-1 \times 100)$.

From the results of this binary logistic regression model, using age as the dependent variable, it can be stated that a decrease in the frequency of the independent variables maintaining a low inventory level, excess storage and transportation dependency will increase the likelihood of the 
retailer's survival (for 5 years or longer) and that an increase in the frequency of the independent variables transportation cost-efficiency and delivery mode will increase the likelihood of the retailer's survival (for 5 years or longer).

\section{Binary logistic regression model: Dependent variable annual income growth}

Before the results of the binary logistic regression model are discussed, the following should be noted regarding the validity and reliability of the logistic regression model predicting the small retailers' survival in terms of annual income growth:

- The Hosmer and Lemeshow test indicated goodness of fit of the logistic regression model with a $p$-value of 0.494 . Therefore the model is assumed to be adequate.

- The overall correct prediction classification improved from $74.2 \%$ (Model 0 - business income contracted or stayed the same) to $76.4 \%$ (Model 1 - business income

TABLE 4: Summary of the 12 independent variables.

\begin{tabular}{|c|c|}
\hline Independent variables & Description of the independent variable \\
\hline Excess storage & Factor (E3j, E3k). \\
\hline Convenience level & Factor (E11j, E11k, E11m). \\
\hline Maintaining a high inventory level & Factor (E3a, E3b, E3d). \\
\hline Maintaining a low inventory level & Factor (E3c, E3e, E3f, E3g, E3h). \\
\hline Product offering & Factor (E11a, E11c). \\
\hline Transportation dependency & Factor (D2f, D2e). \\
\hline Transportation cost-efficiency & Factor (D2b, D2c, D2g). \\
\hline Delivery mode & Factor (D2a, D2d). \\
\hline Rate of purchasing inventory & $\begin{array}{l}\text { E2 - as discussed earlier, because the question } \\
\text { has a single response a principal component } \\
\text { analysis cannot be conducted on the question. } \\
\text { Consequently, the question was added as an } \\
\text { item to the independent variables of the } \\
\text { binary logistic regression model. }\end{array}$ \\
\hline $\begin{array}{l}\text { Higher delivery cost for earlier } \\
\text { inventory delivery }\end{array}$ & $\begin{array}{l}\text { D3 - as discussed earlier, because the question } \\
\text { has a single response a principal component } \\
\text { analysis cannot be conducted on the question. } \\
\text { Consequently, the question was added as an } \\
\text { item to the independent variables of the } \\
\text { binary logistic regression model. }\end{array}$ \\
\hline $\begin{array}{l}\text { Having products immediately } \\
\text { available }\end{array}$ & $\begin{array}{l}\text { E6a - a factor could not be created as the } \\
\text { Cronbach's alpha value is below the acceptable } \\
\text { threshold; consequently, the question was } \\
\text { added as an item to the independent variables } \\
\text { of the binary logistic regression model. }\end{array}$ \\
\hline $\begin{array}{l}\text { Perception that customers know } \\
\text { retailers have enough inventory }\end{array}$ & $\begin{array}{l}\text { E6c - a factor could not be created as the } \\
\text { Cronbach's alpha value is below the acceptable } \\
\text { threshold; consequently, the question was } \\
\text { added as an item to the independent variables } \\
\text { of the binary logistic regression model. }\end{array}$ \\
\hline
\end{tabular}

grew over the past year). Therefore, the results of the binary logistic regression model with the dependent variable income growth over the past year are discussed.

Table 6 provides the results of the 12 independent variables that were included in the binary logistic regression model. Three independent variables were identified as statistically significant predictors of the model ( $p$-values $\leq 0.05$ ). The odds ratios of these three independent variables were considered in order to determine whether the independent variables had a positive or negative influence on the dependent variable. An odds ratio larger than 1 indicates that the independent variable increases the small retailers' odds of growing their annual income, whereas an odds ratio smaller than 1 indicates that the independent variable decreases their odds of growing their annual income.

The results indicated that the following independent variables are statistically significant predictors, at the 5\% level of significance, of the annual income growth (in terms of income change patterns) of the business: maintaining a low inventory level; maintaining a high inventory level; and delivery mode. Having allowed for the other variables in the equation, the odds ratios of the 12 independent variables further indicated that:

- Each decrease in the frequency of maintaining a low inventory level increases the odds of the business's survival (growing their annual income) by $159.07 \%\left(\frac{1}{0.386}\right)$.

- Each increase in the frequency of maintaining a high inventory level increases the odds of the business's survival (growing their annual income) by $232.9 \%$ (3.329 more likely).

- Each increase in the frequency of delivery mode increases the odds of the business's survival (growing their annual income) by $75 \%$ (1.750 more likely).

A decrease in the frequency of the independent variable maintaining a low inventory level will decrease the likelihood of the retailer's survival (growing their income), and an increase in the frequency of the independent variables maintaining a high inventory level and delivery mode will increase the survival of the retailers (growing their income).

TABLE 5: Independent variables in the equation for the binary logistic regression model with the dependent variable age.

\begin{tabular}{|c|c|c|c|c|c|c|}
\hline Independent variables & Beta coefficient & SE & Wald & df & Sig. & Odds ratio $(\operatorname{Exp}[B])$ \\
\hline Maintaining a low inventory level & -0.583 & 0.181 & 10.335 & 1 & 0.001 & 0.558 \\
\hline Maintaining a high inventory level & -0.155 & 0.211 & 0.539 & 1 & 0.463 & 0.856 \\
\hline Product offering & 0.178 & 0.203 & 0.770 & 1 & 0.380 & 1.195 \\
\hline Excess storage & -0.526 & 0.146 & 12.905 & 1 & 0.000 & 0.591 \\
\hline Convenience level & 0.078 & 0.239 & 0.099 & 1 & 0.753 & 1.078 \\
\hline Transportation dependency & -0.448 & 0.164 & 7.450 & 1 & 0.006 & 0.639 \\
\hline Transportation cost-effectiveness & 0.735 & 0.294 & 6.233 & 1 & 0.013 & 2.048 \\
\hline Delivery mode & 0.589 & 0.220 & 7.147 & 1 & 0.008 & 1.802 \\
\hline Having products immediately available & 0.105 & 0.180 & 0.338 & 1 & 0.561 & 1.111 \\
\hline Perception of customers that retailers have enough inventory & -0.031 & 0.160 & 0.037 & 1 & 0.848 & 0.970 \\
\hline Rate of purchasing inventory & 0.017 & 0.099 & 0.030 & 1 & 0.863 & 1.017 \\
\hline Higher cost for earlier inventory delivery & 0.203 & 0.323 & 0.396 & 1 & 0.529 & 1.226 \\
\hline Constant & -0.365 & 1.346 & 0.073 & 1 & 0.786 & 0.694 \\
\hline
\end{tabular}

$\mathrm{SE}$, standard error; df, degrees of freedom; $\operatorname{Exp}(B)$, exponentiation of the $B$ coefficient. 
TABLE 6: Independent variables in the equation for the binary logistic regression model with the dependent variable income growth.

\begin{tabular}{|c|c|c|c|c|c|c|}
\hline Independent variables & Beta coefficient & SE & Wald & df & Sig. & Odds ratio (Exp[B]) \\
\hline Maintaining a low inventory level & -0.9520 & 0.209 & 20.776 & 1 & 0.000 & 0.386 \\
\hline Maintaining a high inventory level & 1.2030 & 0.268 & 20.180 & 1 & 0.000 & 3.329 \\
\hline Product offering & 0.2200 & 0.242 & 0.830 & 1 & 0.362 & 1.246 \\
\hline Excess storage & -0.3050 & 0.165 & 3.401 & 1 & 0.065 & 0.737 \\
\hline Convenience level & -0.0380 & 0.271 & 0.020 & 1 & 0.888 & 0.963 \\
\hline Transportation dependency & -0.3110 & 0.191 & 2.649 & 1 & 0.104 & 0.732 \\
\hline Transportation cost-efficiency & 0.2150 & 0.325 & 0.438 & 1 & 0.508 & 1.240 \\
\hline Delivery mode & 0.5600 & 0.273 & 4.213 & 1 & 0.040 & 1.750 \\
\hline Having products immediately available & -0.1560 & 0.204 & 0.584 & 1 & 0.445 & 0.856 \\
\hline Perception of customers that retailers have enough inventory & -0.0670 & 0.179 & 0.139 & 1 & 0.709 & 0.935 \\
\hline Rate of purchasing inventory & -0.0143 & 0.116 & 1.512 & 1 & 0.219 & 0.867 \\
\hline Higher cost for earlier inventory delivery & 0.1310 & 0.369 & 0.126 & 1 & 0.723 & 1.140 \\
\hline Constant & -2.0240 & 1.582 & 1.636 & 1 & 0.201 & 0.132 \\
\hline
\end{tabular}

$\mathrm{SE}$, standard error; $\mathrm{df}$, degrees of freedom; $\operatorname{Exp}(\mathrm{B})$, exponentiation of the B coefficient.

\section{Conclusion}

Soweto, South Africa's largest township, has been the focus of numerous policymakers wishing to develop initiatives in order to cultivate the township into liveable and vibrant economic centres, which has included the erection of large shopping malls. Despite these initiatives, Soweto is unfortunately still characterised by low levels of entrepreneurial activity, a low survival rate of small businesses and a lack of business skills by the owners and managers of these businesses. The World Bank stressed that these challenges can be addressed through supply chain integration, which entails the building of relationships and skilled processes within and across township boundaries. The logistics activity facilitates these relationships between the different role players in their supply chain by managing the three logistical supply chain drivers to coordinate the flow of products, services and information. The aim of this article was to investigate whether the management of the logistical supply chain drivers can increase the odds of formal independent small Sowetan retail businesses surviving.

From the literature, the age of the small retailer as well as the growth in annual income were identified as suitable measures of survival. Any small business reaching the age of 5 years (or older) or reflecting a growth in annual income is deemed as surviving in the South African business environment. Based on the data obtained from 556 formal independent small retail businesses operating within Soweto, it was established that these small retailers are surviving, as the majority have existed for 5 years or longer. However, they are not reaching their full potential, as seen in the low percentage $(25 \%)$ of retailers reporting an increase in annual income. Using the age of the business and the growth in annual income as dependent variables, two binary logistic regression models were developed to determine whether the management of the three logistical supply chain drivers could predict the small retailers' odds of survival.

From the questions pertaining to the three logistical supply chain drivers, 12 independent variables were identified. The two independent variables relating to the logistical supply chain driver of facilities considered the amount of excess storage at the facility and the in-store convenience level presented to customers. The six independent variables relating to the logistical supply chain driver of inventory considered the level of inventory that the retailers hold (maintaining either a low or high inventory level), having products available immediately, perception of customers that the retailer has enough inventory, the product offering of the retailers and paying a higher delivery cost for earlier inventory delivery. The four independent variables relating to the logistical supply chain driver of transportation considered the retailers' dependency on others for the transportation of inventory, transportation cost-efficiency relating to transportation, delivery mode and paying a higher delivery cost for earlier inventory delivery.

From the binary logistic regression models it could be determined whether the management decisions pertaining to the three logistical supply chain drivers were predictors of small retailers' survival. From the literature, suggestions were made regarding the management of the three logistical supply chain drivers based on the results of the binary logistic regression models. The results of the two binary logistic regression models showed that the management of the three logistical supply chain drivers influences the odds of the small retailers surviving for 5 years or longer as well as their odds of growing their annual income by (1) holding more inventory or (2) increasing the frequency of their delivery mode. From the literature it follows that survival is possible by:

- Holding more inventory: This could increase the retailer's ability to respond quickly to customers' needs, thereby increasing the retailer's level of responsiveness. On the other hand, retailers could also lower costs by benefiting from economies of scale through purchasing inventory in bulk. Having ample products available or competing with lower priced products would increase the retailer's competitiveness.

- Increasing the frequency of their delivery mode: Retailers can collect inventory more often from their suppliers by using their own transportation, by hiring a small truck or by having their inventory delivered directly to their store by suppliers. Retailers can also purchase inventory 
in bulk to benefit from economies of scale and to qualify for free delivery. On the other hand, by collecting inventory from suppliers themselves, retailers would increase their flexibility as they would be in control of the transportation of inventory and can easily adapt to market changes by stocking sufficient inventory.

In addition to the results and suggestions already discussed, the binary logistic regression model with the dependent variable of age also indicated that (3) decreasing excess facility capacity or (4) being less dependent on transportation opportunities and other retailers for the transportation of their inventory influence the odds of small retailers surviving for 5 years or longer. From the literature it follows that survival is possible by:

- Decreasing excess facility capacity: Minimising the amount of excess capacity that the retailer has will lower the amount spent on a facility but will directly influence the number of inventory items purchased because of restricted storing capacity. Although decreasing the amount of excess capacity is a viable option for retailers to increase survival, it might not be the best option because of the lack of storage space available in townships, as found by the World Bank.

- Being less dependent on transportation opportunities and other retailers for the transportation of their inventory: Being less dependent is a viable option because the World Bank confirmed that township retailers find it easy to transport their inventory to their store. By being less dependent, the retailers take responsibility for the transportation of the inventory, which would lead to an increase in flexibility. The literature confirmed that keeping transportation costs low provides a competitive advantage to retailers and that the R300 to R350 transportation costs that the retailers incur might be less expensive than having the inventory delivered by a supplier. Another option would be to consider purchasing in bulk from suppliers to qualify for free delivery.

The findings of this study show that management of the three logistical supply chain drivers influences the odds of small township retailers' survival in terms of age and annual income growth. Before owners or managers make any managerial changes regarding logistical supply chain drivers, the impact of such changes in terms of responsiveness and cost-efficiency should be considered in order to stay aligned with the overall goal of the supply chain. Policymakers should consider the findings of this study when designing developmental initiatives for townships, as the management of the logistical supply chain drivers directly influences small retailers' odds of survival. Further research needs to be conducted to determine whether the suggestions made, based on the literature, on how to manage the three logistical supply chain drivers to increase small retailers' survival are viable options, especially within the unique economic environment of Soweto. Additionally, further research should be conducted to determine whether the industry in which small retailers operate will influence the results of the study because the products (functional or innovative) that the retailers sell will differ between the different industries.

\section{Acknowledgements}

T.E. is a lecturer and graduate student at the University of South Africa. This article is based on her master's dissertation, completed in 2017.

\section{Competing interests}

The authors declare that they have no financial or personal relationships that may have inappropriately influenced them in writing this article.

\section{Authors' contributions}

J.O.C. was the supervisor of T.E.'s master's dissertation and contributed to the conceptualisation of the article, as well as analysing and recording literature and empirical findings from the dissertation.

\section{References}

Abor, J. \& Quartey, P., 2010, 'Issues in SME development in Ghana and South Africa', International Research Journal of Finance and Economics 39, 218-228.

Alfalla-Luque, R., Mendina-Lopez, C. \& Dey, P.K., 2013, 'Supply chain integration framework using literature review', Production Planning and Control 24(8-9) 800-817. https://doi.org/10.1080/09537287.2012.666870

Ambe, I.M., 2012, 'Determining an optimal supply chain strategy', Journal of Transport and Supply Chain Management 6(1), 126-147. https://doi.org/10.4102/jtscm. v6i1.35

Aykan, E., Aksoylu, S. \& Sönmez, E., 2013, 'Effects of support programs on corporate strategies of small and medium-sized enterprises', Procedia - Social and Behavioural Sciences 99, 938-946. https://doi.org/10.1016/j.sbspro.2013.10.567

Badenhorst-Weiss, J.A. \& Cilliers, J.O., 2014 , 'Competitive advantage of independent small businesses in Soweto', Southern African Business Review 18(3), 1-21.

Badenhorst-Weiss, J.A., Cilliers, J.O. \& Eicker, T., 2014, 'A unique market offering by formal independent retail and wholesale small businesses in Soweto township, South Africa', Problems and Perspectives in Management 12(4), township,

Badenhorst-Weiss, J.A., Van Biljon, E.H.B. \& Ambe, I.M., 2017, Supply chain management: $A$ balanced approach, 2nd edn., Van Schaik, Pretoria.

Baily, P., Farmer, D., Crocker, B., Jessop, D. \& Jones, D., 2008, Procurement principles and management, 10th edn., Harlow, Essex, Financial Times, Prentice Hall.

Berger, E.B., 2017, Introduction to Binary Logistic Regression and propensity score viewed 31 August 2018, from https://www.researchgate.net/publication/ 320505159 Introduction_to_Binary_Logistic_Regression_and_Propensity Score_Analysis

Bowersox, D.J., Closs, D.J., Cooper, M.B. \& Bowersox, J.C., 2013, Supply chain logistics management, 4th edn., McGraw-Hill Irwin, New York.

Chi, T., Kilduff, P.P. \& Gargeya, V.B., 2009, 'Alignment between business environment characteristics, competitive priorities, supply chain structures, and firm business performance', International Journal of Productivity and Performance Management 58(7), 645-669. https://doi.org/10.1108/17410400910989467

Chopra, S. \& Meindl, P., 2016, Supply chain management: Strategy, planning, and operation, 6th edn., Pearson, Harlow, Essex.

Christopher, M., 2016, Logistics \& supply chain management, 5th edn., Pearson Higher Education, Harlow.

Darbi, W.P.K., Hall, C.M. \& Knott, P., 2018, 'The informal sector: A review and agenda for management research', International Journal of Management Reviews 20(2), 301-324. https://doi.org/10.1111/ijmr.12131

Das Nair, R. \& Dube, S., 2015, The expansion of regional supermarket chains: Changing models of retailing and the implications for local supplier capabilities in South Africa, Botswana, Zambia, and Zimbabwe, viewed 31 August 2018, from https:// ssrn.com/abstract=2923047 or https://doi.org/10.2139/ssrn.292304

Deijl, C., De Kok, J. \& Essen, V.V., 2013, Is small still beautiful? Literature review of recent empirical evidence on the contribution of SMEs to employment creation, German Association for International Cooperation.

Diepsloot, 2017, Diepsloot, viewed 11 April 2017, from http://www.diepsloot.com

Du Plessis, P.J., Strydom, J.W. \& Jooste, C.J., 2012, Marketing management, 6th edn., Cape Town, Juta. 
Ehrenthal, J.C.F., Honhon, D. \& Van Woensel, T., 2014, 'Demand seasonality in retail inventory management', European Journal of Operational Research 238(2) 527-539. https://doi.org/10.1016/j.ejor.2014.03.030

Esarey, J. \& Pierce, A., 2012, 'Assessing fit quality and testing for misspecification in binary-dependent variable models', Political Analysis 20(4), 480-500. https://doi. org/10.1093/pan/mps026

Fawcett, S.E., Ellram, L.M. \& Ogden, J.A., 2007, Supply chain management: From vision to implementation, 1st edn., Pearson, Upper Saddle River, NJ.

Fourie, F. \& Kerr, A., 2017, Informal sector employment creation in South Africa: What

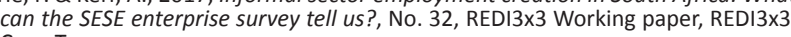
Cape Town.

Gauteng Department of Economic Development, 2014, Gauteng Department of Economic Development revitalisation strategy, viewed 23 January 2016, from http://www.ecodev.gpg.gov.za/Documents/Draft\%20GTER\%20Strat.pdf

Gauteng Quarterly Bulletin, 2012, The retail industry on the rise in South Africa viewed 20 October 2017, from http://www.treasury.gpg.gov.za/Documents/ viewed 20 October 2017, from http://www.treasury.gpg.gov.
QB1\%20The \%20Retail\%20Industry\%200n\%20the\%20Rise.pdf

Goldsby, T.J., Iyengar, D. \& Rao, S., 2014, The definitive guide to transportation Principles, strategies, and decisions for the effective flow of goods and services, 1st edn., Pearson, Upper Saddle River, NJ.

Graungaard Pedersen, S., Zachariassen, F. \& Stentoft Arlbjørn, J., 2012, 'Centralisation vs. de-centralisation of warehousing: A small and medium-sized enterprise perspective', Journal of Small Business and Enterprise Development 19(2), 352-369. https://doi.org/10.1108/14626001211223946

Hines, T., 2013, Supply chain strategies: Demand driven and customer focused, 2nd edn., New York, Routledge.

Holter, A.R., Grant, D.B., Ritchie, J. \& Shaw, N., 2008, 'A framework for purchasing transport services in small and medium size enterprises', International Journal of Physical Distribution \& Logistics Management 38(1), 21-38. https://doi.org/ 10.1108/09600030810857193

Hosmer, D.W. \& Lemeshow, S., 2000, Applied logistic regression, 2nd edn., New York, Wiley.

Hugo, W.M.J. \& Badenhorst-Weiss, J.A., 2011, Purchasing \& supply management, 6th edn., Van Schaik, Pretoria.

Hugos, M., 2006, Essentials of supply chain management, Wiley, Hoboken, NJ.

Jamali, D., Lund-Thomsen, P. \& Jeppesen, S., 2017, 'SMEs and CSR in developing countries', Business \& Society 56(1), 11-22. https://doi.org/10.1177/000765031 5571258

Kamath, N.B. \& Roy, R., 2007, 'Capacity augmentation of a supply chain for a shor lifecycle product: A system dynamics framework', European Journal of Operational Research 179(2), 334-351. https://doi.org/10.1016/j.ejor.2006.03.045

Katz, J.A. \& Green, R.P., 2012, Entrepreneurial small businesses, 3rd edn., McGraw-Hill, New York.

Kotler, P., Burton, S., Deans, K., Brown, L. \& Armstrong, G., 2013, Marketing, 9th edn. Pearson, Frenchs Forest, Australia.

Lawrence, A.S., Sivakumar, B. \& Arivarignan, G., 2013, 'A perishable inventory system with service facility and finite source', Applied Mathematical Modelling 37(7), 4771-4786. https://doi.org/10.1016/j.apm.2012.09.018

Ligthelm, A.A., 2010, 'Entrepreneurship and small business sustainability', Southern African Business Review 14(3), 131-153.

Ligthelm, A.A., 2013, 'Confusion about entrepreneurship? Formal versus informal small businesses', Southern African Business Review 17(3), 57-75.

Louw, A. \& Jordaan, D., 2016, 'Supply chain risks and smallholder fresh produce farmers in the Gauteng province of South Africa', Southern African Business Review 20(1), 286-312.

Mbonyane, B. \& Ladzani, W., 2011, 'Factors that hinder the growth of small businesse in South African townships', European Business Review 23(6), 550-560. https:// doi.org/10.1108/09555341111175390

Monczka, R.M., Handfield, R.B., Giunipero, L.C. \& Patterson, J.L., 2016, Purchasing and supply chain management, 6th edn., Cengage, Boston, MA.

Mtshali, M., Mtapuri, O. \& Shamase, S.P., 2017, 'Experiences of black-owned smal medium and micro enterprises in the accommodation tourism-sub sector in selected Durban townships, KwaZulu-Natal', African Journal of Hospitality, Tourism and Leisure 6(3), 130-141.

Nel, J.D., 2010, 'Developing a conceptual framework to analyse supply chain design practices', Unpublished doctoral thesis, University of South Africa, Pretoria.
Nkosi, E., Bounds, M. \& Goldman, G., 2013, 'Skills required for the black-owned small enterprise in Soweto', Acta Commercii 13(1), 1-10. https://doi.org/10.4102/ac. v13i1.186

Nwaogbe, O.R., Omoke, V., Ubani, E.C. \& Ukaegbu, S.I., 2013, 'Cost minimisation of product transhipment for physical distribution management', Journal of Transport and Supply Chain Management 7(1), 1-9. https://doi.org/10.4102/ jtscm.v7i1.94

Olawale, F. \& Garwe, D., 2010, 'Obstacles to the growth of new SMEs in South Africa: A principal component analysis approach', African Journal of Business Management 4(5), 729-738

Old Mutual, 2016, The old mutual legends programme then and now, viewed 02 June 2017, from http://www.fetola.co.za/wp-content/uploads/2012/09/LegendsProgramme.pdf

Peyton, S., Moseley, W \& Battersby, J., 2015, 'Implications of supermarket expansion on urban food security in Cape Town, South Africa', African Geographical Review 34(1), 36-54.https://doi.org/10.1080/19376812.2014.1003307

Pienaar, W.J. \& Vogt, J.J., 2012, Business logistics management: A value chain perspective, 4th edn., Cape Town, Oxford.

Prinsloo, D.A., 2014, Retail trends in a very dynamic South African market, Urban Studies, viewed 30 October 2016, from www.urbanstudies.co.za/retail-trends-ina-very-dynamic-south-african-market/

Qrunfleh, S. \& Tarafdar, M., 2013, 'Lean and agile supply chain strategies and supply chain responsiveness: The role of strategic supplier partnership and postponement' Supply Chain Management: An International Journal 18(6), 571-582. https://doi. org/10.1108/SCM-01-2013-0015

Rogan, M. \& Skinner, C., 2017, The nature of the South African informal sector as reflected in the quarterly labour-force survey, 2008-2014, No. 28. REDI3x3 Working paper, REDI3×3, Cape Town.

Rogerson, C.M. \& Rogerson, J.M., 1997, 'The changing post-apartheid city: Emergent black-owned small enterprises in Johannesburg', Urban Studies 34(1), 85-103. https://doi.org/10.1080/0042098976285

SA News, 2011, SMMEs hold key to economic growth, viewed 02 June 2017, from http://www.sanews.gov.za/south-africa/smmes-hold-key-economic-growth.

Small Business Project (SBP), 2015, SME sustainability and growth should be an obsession for job creation in South Africa, viewed 11 April 2017, from http:// www.sbp.org.za/uploads/media/SBP_Alert_-_SME_sustainability_and_growth 01.pdf

Simon, A.T., Serio, L.C.D., Pires, S.R.I. \& Martins, G.S., 2015, 'Evaluating supply chain management: A methodology based on a theoretical model', Revista de Administração Contemporânea 19(1), 26-44. https://doi.org/10.1590/19827849rac20151169

South Africa, National Planning Commission, 2012, National development plan 2030. Our future - make it work, The Presidency, Pretoria.

Statistics South Africa (Stats SA), 2011, Census 2011, viewed 11 April 2017, from http://www.statssa.gov.za/?page_id=4286\&id=11317

Strydom, J.W., 2011, 'Retailing in disadvantaged communities: The outshopping phenomenon revisited', Journal of Contemporary Management 8, 150-172.

Strydom, J.W., 2013, 'Retail patronage of Sowetan consumers after 1994', African Journal of Business Management 7(29), 2863-2871. https://doi.org/10.5897/ AJBM12.1133

Strydom, J.W., 2015, 'David against Goliath: Predicting the survival of formal small businesses in Soweto', International Business \& Economics Research Journal 14(3) 463-476. https://doi.org/10.19030/iber.v14i3.9210

University of the Western Cape, 2016, How can South African entrepreneurs succeed?, viewed 02 June 2017, from https://www.uwc.ac.za/News/Pages/How-Can-SouthAfrican-Entrepreneurs-Succeed.aspx

Van Eeden, S., Viviers, S. \& Venter, D., 2003, 'A comparative study of selected problems encountered by small businesses in the Nelson Mandela, Cape Town and Egol metropoles', Management Dynamics: Journal of the Southern African Institute for Management Scientists 12(3), 13-23.

Wisner, J.D., Tan, K.C. \& Leong, G.K., 2016, Supply chain management: A balanced approach, 4rd edn., South-Western, Boston, MA

World Bank, 2014, Economics of South African townships: Special focus on Diepsloot, The World Bank, Washington, DC. 